ISSN: $1412-4734$

E-ISSN: 2407-8646

Volume 18, Number 2, 2018

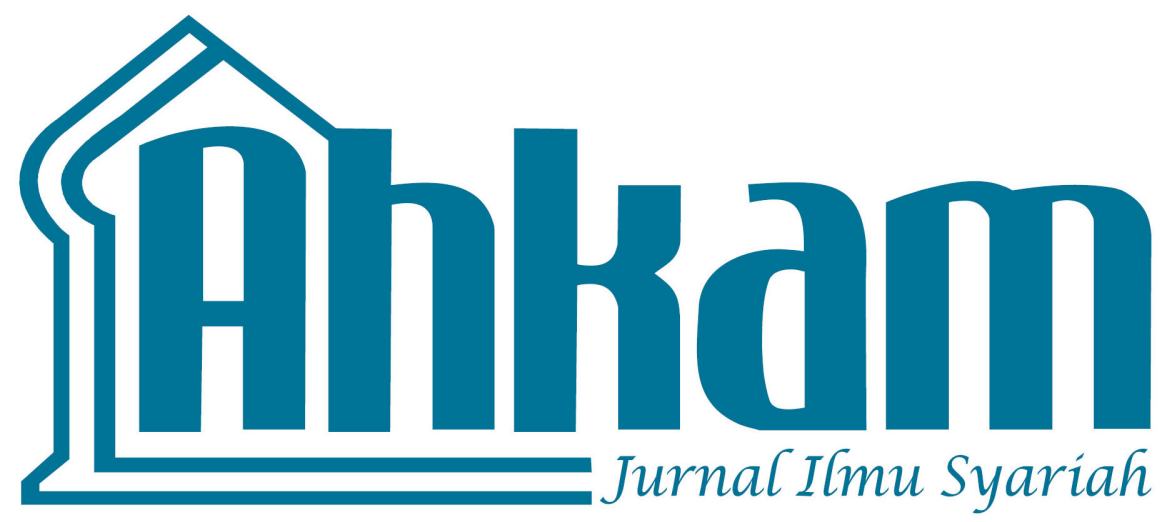

* Arifuddin Muda Harahap

Rules on Wage Standard to Improve Workers' Living Needs in the Perspective of Maqasid Al-Shari'ah

* M. IkHsan TanggoK

Circumcision Law in Christianity and Islam

* Abdul Rohman Zulfikar Alfaroug \& Nurhasanah The Positivisation of National Sharia Board Fatwa About Mudaraba into Financial Service Authority Regulation

* Muhamad Isna Wahyudi

Women Dealing With the Law in Religious Courts

* Arif Hidayatullah \& Anita Priantina

Toward Zakat Management Integration in Indonesia: Problems and Solution

* Muhammad Adil dan Muhamad Harun

Fiqh Melayu Nusantara in the Palembang Darussalam Sultanate Period

* Sugiri Permana

Implications of Hazairin and Munawir Sjadzali Thoughts in Establishment of Islamic Inheritance in Indonesia 


\section{Mhliam}

Volume 18, Number 2, 2018

\section{EDITOR-IN-CHIEF}

Khamami Zada

\section{EDITORS}

Fathudin

Maman R Hakim

Windy Triana

Nur Hidayah

Ahmad Bahtiar

\section{INTERNATIONAL EDITORIAL BOARD}

Tim Lindsey (University of Melbourne Australia)

Nadirsyah Hosen (Monash University Australia)

Ahmad Hidayat Buang (Universiti Malaya Malaysia)

Raihanah Azahari (University Malay Malaysia)

Mark Elwen Cammack (Southwestern University)

Razeen Sappideen (University of Western Sydney)

Carolyn Sappideen (University of Western Sydney)

Nik Ahmad Kamal bin Nik Mahmod (International Islamic Universiti Malaysia)

Ahmad Tholabi Kharlie (UIN Syarif Hidayatullah Jakarta)

Muhammad Atho Mudzhar (UIN Syarif Hidayatullah Jakarta)

Masykuri Abdillah (UIN Syarif Hidayatullah Jakarta)

Muhammad Amin Suma (UIN Syarif Hidayatullah Jakarta)

M. Arsykal Salim GP (UIN Syarif Hidayatullah Jakarta)

Asep Saepudin Jahar (UIN Syarif Hidayatullah Jakarta)

ASSISTANT TO THE EDITORS

Kamal F. Musa

Erwin Hikmatiar

ENGLISH LANGUAGE ADVISOR

Bradley Holland

Umi Kulsum

ARABIC LANGUAGE ADVISOR

Amany Burhanudin Lubis

AHKAM has been accredited based on the determination of Director General of Research Reinforcement and Development, Research, and Technology Ministry of Higher Education of Republic of Indonesia, No. 36/a/E/KPT/2016 (valid until 2021). 
AHKAM Jurnal Ilmu Syariah (ISSN: 1412-4734) is a periodical scientific journal published by Faculty of Sharia and Law of Syarif Hidayatullah State Islamic University Jakarta in collaboration with Indonesian Scientist and Sharia Scholar Association (HISSI). This journal specifically examines the science of sharia and obtains to present various results of current and eminence scientific research. The administrators receive articles as contributions Sharia and Islamic law disciplines from scientists, scholars, professionals, and researchers to be published and disseminated.

\section{EDITORIAL OFFICE:}

Fakultas Syariah dan Hukum UIN Syarif Hidayatullah Jakarta

Jl. Ir. H. Juanda 95 Ciputat, Jakarta 15412

Telp. (+62-21) 74711537, Faks. (+62-21) 7491821

Website: http://journal.uinjkt.ac.id/index.php/ahkam/index

E-mail: Jurnal.ahkam@uinjkt.ac.id 


\section{TABle of Contents}

251 Arifuddin Muda Harahap

Rules on Wage Standard to Improve Workers' Living Needs in the Perspective of Maqasid Al-Shari'ah

265 M. IkHSAN TANGgOK

Circumcision Law in Christianity and Islam

285 Abdul Rohman Zulfikar Alfaroug \& Nurhasanah The Positivisation of National Sharia Board Fatwa About Mudaraba into Financial Service Authority Regulation

305 Muhamad Isna Wahyudi

Women Dealing With the Law in Religious Courts

321 Arif Hidayatullah \& Anita Priantina

Toward Zakat Management Integration in Indonesia:

Problems and Solution

347 Muhammad Adil \& Muhamad Harun

Figh Melayu Nusantara in the Palembang Darussalam Sultanate Period 
375 Sugiri Permana

Implications of Hazairin and Munawir Sjadzali Thoughts in Establishment of Islamic Inheritance in Indonesia

395 RifQi QOWIyul ImAn

The Competence of Religious Court in Indonesia and

Syahadah Istifadhah (Testimonium De Auditu) in Case of Itsbat Waqf

417 Mustapa Khamal Rokan \& Kama Rusdiana Configuration of Costomary Law Related to Economy (Economic Adat Law Study in North Sumatera, Indonesia)

433 Yayan Sopyan \& Muhammad Shofwan Nidzami Nyabek Toloh Marriage Proposal Tradition in Madurese Culture: A Review of The Sociology of Islamic Law

453 Nuryani \& M. Musyafa

Linguistic Review on Marriage Age Regulation

463 Wetria Fauzi

Regulation of Sharia Insurance After the Enactment of Law No. 40 of 2014 Concerning Insurance 


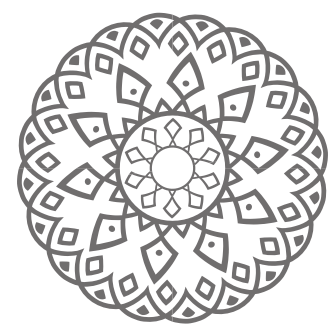

\title{
The competence of Religious Court IN INDONESIA AND SYAHADAH ISTIFADHAH (Testimonium De Auditu) in Case of Itsbat Waqf
}

\author{
Rifqi Qowiyul Iman
}

\begin{abstract}
Abstrak: Tulisan ini mengkaji tentang bagaimana sejatinya kompetensi absolut Pengadilan Agama dan pengguanaan kesasian syahadah istifadhah (testimonium de auditu) dalam hal perkara itsbat Waqf yang diajukan ke Pengadilan Agama sebagai institusi peradilan yang berada di bawah naungan Mahkamah Agung Republik Indonesia. Pada pembahasan ini dijelaskan bagaimana sesungguhnya kompetensi Pengadilan Agama terutama dalam perkara itsbat Waqf sebagaimana di atur dalam Undang-Undang No 3 Tahun 2006 Tentang Peradilan Agama digandengkan dengan UndangUndang Nomor 41 Tahun 2004 Tentang Waqf. Selain itu tulisan ini juga mengkomparasikan konsep syahadah istifadhah dengan konsep testimonium de auditu serta kekuatan hukumnya dalam hal pembuktian di Pengadilan khususnya dalam perkara itsbat Waqf. Tulisan ini menyimpulkan bahwasanya penetapan itsbat Waqf merupakan kewenangan absolut Pengadilan Agama. Selain itu, berdasarkan fiqh syahadah istifadhah dapat digunakan sebagai alat bukti dalam penetapan itsbat Waqf.
\end{abstract}

Kata kunci: itsbat waqf, pengadilan agama, syahadah istifadhah, testimonium de auditu 
Abstract: This paper examines how exactly the absolute competence of the Religious Courts and the application of syahadah istifadhah (testimonium de auditu) in the case of waqf determination submitted to the Religious Court as a judicial institution under the Supreme Court of the Republic of Indonesia. In the discussion, it is explained how the competence of the Religious Court especially in the case of waqf determination as arranged in Law No. 3 Year 2006 About Religious Courts combined with Law Number 41 Year 2004 About Waqf. In addition, this paper also compares between the concept of syahadah istifadhah and testimonium de auditu also its legal force in the case of verification at the court especially in the case of waqf determination. This paper concludes that the assignment of Waqf is the absolute authority of the Religious Courts. In addition, according to Islamic jursiprudence syahadah istifadhah can be used as a means of proof in waqf determination.

Keywords: waqf, Religious Court, syahadah istifadhah, testimonium de auditu

$$
\begin{aligned}
& \text { ملخص: تبحث هذه الورقة في مدى كفاءة الاختصاص المطلق للمحاكم الدينية وتطبيق }
\end{aligned}
$$

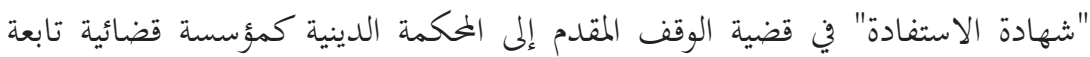

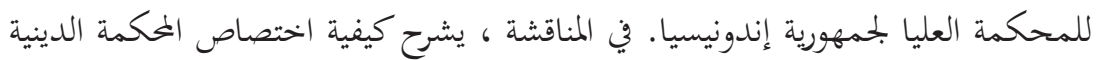

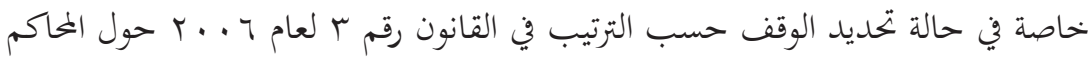

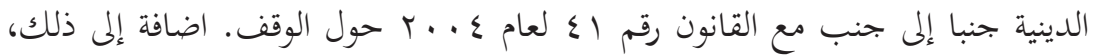

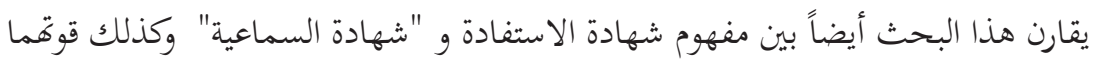

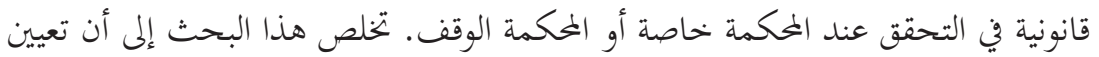

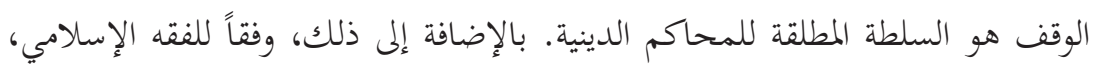

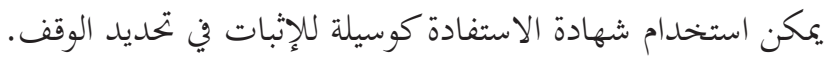

$$
\begin{aligned}
& \text { الكلمات المفتاحية: الوقف، المحاكم الدينية شهادة الاستفادة، شهادة السماعية }
\end{aligned}
$$




\section{Introduction}

In this modern era, waqf as one of Islamic philanthropy has started to be regarded as a strategic means of national economic development. In this case, waqf actually has a significant role after zakat especially in terms of poor community empowerment. Moreover, among the characteristics of waqf that the nominal amount of waqf must remain was in contrast to others which were directly discharged after use.

The philosophy of waqf which maintain the asset which is different form zakat, infaq and shadaqah considered as more superior. With the persistence of waqf assets, the benefit for community will be achieved countinously. From the aspect of eternity objects and values, waqf can provide benefits to the widest public mob for the long term. Besides the management of waqf may be distributed or used by rich people who are not entitled to receive zakat (Kencana, 2017; p.5)

Various studies have been innumerable in order tu discuss the potential of waqf in Indonesia. Based on data collected by Indonesian Ministry of Religion per March 2016, the number of waqf land in Indonesia reached $4.359 .443 .170 \mathrm{~m}^{2}$ spread over 435.768 locations in 33 provinces. That number increased by almost 100 per cent when compared with the data of waqf land in 2007 which amount to 2.686.536.657 $\mathrm{m}^{2}$ and spread over 366.595 locations (Badan Wakaf Indonesia, 2018). This amount does not include cash waqf collected by Zakat Institutions in Indonesia. According to Badan Waqf Indonesia, asset of cash waqf has been collected in Indonesia reached $145.8 \mathrm{M}$ per December 2013. This number will continusly grow as the potential of cash waqf in Indonesia amounted to 120 trillion per year (Noor, Fathoni \& Cholil, 2017; p. 13).

Both rapid development and increasing potential are not happening without consequences. The greater potential for disputes occur as the proliferation of waqf transactions occur. Proven in the past five years, the case of disputes waqf into the Religious Courts showed an increasing trend, although the amount is not as much as heritage and divorce case.

Problems of waqf disputes in Religious Courts are rarely discussed, one of them because only a little amount of disputes of waqf resolved through litigation path. Although Article 62 of Law Number 41 Year 
2004 about waqf and its explanation states that the dispute of waqf settlement through adjudicative path at Religious Courts / Mahkamah Syar'iyah is the last step (not an option) after the mechanism of consensus, mediation and arbitration failed. After all it is predicted that future waqf disputes will increase and become more complex. This plus the fact that 34 percent of the total waqf land in Indonesia does not have a certificate. In fact, one of the most common causes of disputes in waqf is about absence of a valid certificate on the donated land (Direktorat Jendral Badan Peradilan Agama, 2017; p. 3).

In this current era, the legal acts of waqf must be evidenced by the deed of waqf statement. The deed of waqf statemet in this case serves as a proof of authenticity at the same time guarantees to prevent misuse or pilferage rights. In fact, in some communities many waqf practices in the past were found without any written evidence. Among the causes is because waqf on past only based on feelings of sincere struggle to raise religion Islam without requiring authentic written, besides the cause of fiqh perspective, the past also did not oblige written evidence in any waqf legal acts. Therefore, in these days there are many application made in order to determine waqf throught Religious Courts. Furthermore, the question arises of how exactly the Religious Courts absolute competence in handling this case.

Other problems connected with proceedings of itsbat waqf is about application of istifadhah witness (as-syahadah bi al-istifadhah) as the basis of itsbat waqf acceptance. It is known that the waqf in the ancient times only made orally also the witnesses as well as either perpetrator or nazhir had passed away. Based on this, it is necessarly need to understand depthly how the actual concept of syahadah istifadhah in terms of determinating itsbat waqf in the Religious Court of Indonesia.

\section{Absolute Competence of Religious Court in Indonesia}

Competence means absolute authority of a court to judge based on the material law (Mardani, 2009; p. 53). Absolute competence or attributie van rechtsmacht (in Dutch) is the authority concerning the division of powers between the judicial bodies (Sutiantio \& Oeripkartawinata, 2009; p. 11). In other words, the absolute competence is the authority on the problem areas that have specifically been regulated in the legislation to be the right of examining, decidinng 
and judging. Judging authority of these case areas is absolute, meaning that what has been determined to be the power jurisdiction of courts, become the absolute authority without being able to be intervened by other jurisdictions (Harahap, 2005; p. 102).

Mukti Arto (2004; p. 6) said that there are two priciples to determine the absolute competence of Religious Courts, these principles are as follows:

1. If a case involves the legal status of a Muslim, and / or

2. A dispute arising from an act or event of law made or incurred under Islamic law or closely related to the legal status as Muslims.

And in adjudicating cases that became their authority, the Religious Court must adhere to the principles of Islamic personality (Mahfud M.D, 1993; p. 40), as stated in Article 2 of Law No. 3 Year 2006 as amending Law No. 7 Year 1989 on the Religious Court;

"Justice Religion is one of the institutions of judicial power for Moslems people seeking justice regarding any particular case ruled by this legislation ".

This means that the litigant parties should be equally Muslim or in the event of legal relations, the two sides are both Muslim.

As a judicial institution based on Islamic law, the Religious Court is called a special court. It is because the Religious Courts judge cases that are determined exclusively by the legislation, which is specifically authorized only to judge certain case matters or about specific group of people. In this case, the Religious Court is only authorized in certain areas of civil, not including the criminal field and also just for Moslems in Indonesia, in cases of Islamic civil law (Djalil, 2006; p. 9). It is because the majority of Indonesian people are Moslims.

Amendments of Law No. 7 Year 1989 by Law No. 3 Year 2006 and Law No. 50 Year 2009, is essentially to adapt to Law No. 48 Year 2009 on Judicial Power and Law No. 3 Year 2009 on the second amendment of Law No. 14 Year 1985 on the Supreme Court. The amendment means also that the basis of overall policy has been laid and hence all matters concerning the Religious Courts, whether related with the technical judicial or non judicial such as organization, administration and finance are under the authority of the Supreme Court. Besides, changes in Law No. 7 of 1989, will further strengthen the position and 
existence of the Religious Court itself in the system of law in Indonesia (Rahmi, 2013; p. 3).

One of the changes which is also considered as significant towards Law No. 7 Year 1989 is the Article 49 concerns the absolute authority of the Religious Courts. As stated in Law No. 3 of 2006 Article 49 explains that:

"The Religious Court duty and authority are to examine, decide and resolve cases at the first level among people who are Muslims in the areas of: (a) marriage; (b) heritage; (c) testament; (d) grants; (e) waqf; (F) zakat; (G) infaq; (H) shadaqah; and (g) Shari'ah economy".

In such changes expanded the authority of the Religious Courts. These expansion would include zakat, infaq, and object of disputes over property rights with the subject of legal between Moslems and also Shari'ah economic.

\section{Istbat Waqf, Syahadah Istifadhah and Absolute Competence of Religious Court Itsbat Waqf}

Itsbat waqf consists of two Arabic syllables both are al-istbat and alwaqf. Al-istbat etymologically means assume that something is always upright / fixed and correct (Ibn Manzhur, 1968; Vol. 2, p. 20). While the terminology of al-itsbat as stated by Moslem scholar means filing legal evidence (ad-dalil ash-shar'i) in the presence of the judges ( $q a d h i)$ on a truth or a particular event. While in the Big Indonesian Dictionary the word "itsbat" is defined as the determination of the truth (validity) of a case.

While al-waqf literally means "holding" (al-habsu), it can also be interpreted as "prohibiting" (al-man'u). The word waqf in Arabic language can also be interpreted as an object of waqf (Wizarat Al-Awqaf wa As-Syu'un Ad-Diniyah, 1983; vol. II, p. 323)

While the term of waqf have varied definitions as will be explained as the following:

1. The jurists of Hanafi stated that waqf is to resist the material possessions on the legal basis of ownership of God and distribute benefits to whom He wills. This definition is expressed by two companions of Abu Hanifah. 
2. Abu Hanifa stated that waqf is to resist material on the legal of waqif ownership of property and distribute although overall benefits (means includes waqf for personal self, poor, or rich people as stated in Rad al-Mukhtar) (Ibn Abidin, 2003; vol. 6, p. 519).

3. Ibn Arafah form Maliki jurist gives the definition of waqf by classifying words as a verbal noun (al-mashdar) and noun (alism). Waqf as verbal noun means giving the benefit of an object during the period its existence while maintaining ownership of waqif even limited only by recognition. While waqf as noun (alisim) means an object which taken its usefulness as long as its existence (Wizarat Al-Awqaf wa As-Syu'un Ad-Diniyah, 1983; vol. 44, p. 108).

4. Syafi'iyah scholars stated that waqf is holding treasures that can be used on things that are permissible, as well as the eternal of its material by breaking the owner rights of management (AsSyarbini, 1997; Vol. 2, p. 205).

5. Jurists of Mazhab Hambali stated that waqf is to resist a property that can be used while maintain eternity of the material and break off management rights of the owner or other party and use it on good things as a form of approach to Allah SWT (Al-Buhuti, 2000; Vol. 4, p. 329).

6. Pursuant to Article 215 paragraph (1) Compilation of Islamic Law, waqf is a legal act of a person or group of persons or legal entities that separates most of her possessions and instituted them in perpetuity for the benefit of worship or other public needs in accordance with Islamic thoughts.

Based on the exposure above it can be concluded that itsbat waqf means to establish and strengthen the identity of the object that has been endowed by waqif which previously has no signs of written evidence such as deed of waqf statement or any other certificate.

\section{Syahadah Istifadhah Definition}

Syahadah etymologically means a valid information (al-khabar alqathi ), recognition/testimony (al-iqrar). Epistimologically, the word 
"syahadah" has several different meanings:

1. Syahadah means recognition (al-iqrar)

In this case Islamic scholars define syahadah as a statement of a truth upon yourself to another party.

2. Syahadah means testimony

In this case Moslem jurists define syahadah as a statement of a truth upon the other parties to the other party before the Tribunal of judges.

This discussion will be focused on the definition of the syahadah as telling the truth over someone to the other before a Tribunal judge (ikhbarun bi haqq al-lilghair' ala ghair fi majlis al-qada).

While istifadhah comes from the word fadha which means abundance. The word is commonly used to describe the abundant water overflowed from it place of flow. The word istafadha also means intasyara and $d z a^{\prime} a$ (spread), in this case the author of Lisan Al-Arab (1968; Vol. 7, p. 212) described it as the widespread talks (istafadha al-hadeeth).

Based on its etimology meaning, istifadhah can be expressed as the state where the object of the testimony has been widespread among audiences where each one of them listen to each other's information. Istifadhah usually occurs on a number of things which cannot be known unless it is based on what is heard.

\section{Levels of Syabadab Istifadhab}

In terminology of Fiqh, syahadah istifadhah often referred by using the term "as-syahadah bit tasamu" (the testimony of the mutual listening). In this case, the Islamic scholars categorizes them into several levels, such as the following:

1. Testimony with valid degree of truth and factual information, this kind of witness also called as-syahadah bis-sima' al-mutawatir (testimony form sure hearing). As the examples are testimony to the existence of a town called Makkah, Madinah, Cairo etc. In this case the information is certainly undeniable even though it comes from a man who has never seen the places directly. In this sort of thing, the testimony must be accepted as well as having the same position with the actual testimony. 
2. Testimony with the strong level of presupposition to approach the truth. In such a case, the information (khabar) has been widespread in the community amount to quite a lot. For example when the new moon of Ramadan can be seen by many people and the news about it have been widespread among the inhabitants of a country, then it is mandatory for anyone wether who saw it or not to fast. In such circumstances, the testimony before the judge is not needed as well as no longer validation needed for the information.

3. Testimony with the strong level of prejudice but different from prejudices mentioned above in terms of the appropriateness of the source of information.

\section{Requirements to Accept Syahadah Istifadhab}

After having explained about definitions and levels of syahadah istifadhah, hereafter fuqaha provides some requirements to accapte syahdah istifadhah. In this paper, the author will be presented in summary some of the terms considered important as follows:

1. The testimony should came from two righteous people (syahidain ' adlain) in the famous opinion. However it is argued the testimony like this should come from four witnesses.

2. The testimony should be unquestioned. For example when there are three teenagers aged eighteen give one testimony while in the community there are hundreds of teenagers in their age but did not know anything, then the testimony rejected instantly. But when the doubts vanished, then such testimony is acceptable.

3. The news or information has spread widely and become many people's knowledge.

4. The people who will testify should take an oath first.

\section{The Cases Where Syahadah Istifadhah Can be Considered Evidence}

In fact, there is no difference of opinion among fuqaha about the validity of syahadah istifadhah although in this case the witnesses not witnessed what happened by their own eyes. Because the substance of this kind of testimony is fame and dissemination, where this principle is replacing personal witness over the things that happen. 
Fuqaha have different opinions about what kind of case that its witness can be made with this method. Here are some opinions of scholars about this problem:

1. Cross of opinion occurs between Maliki Scholars about cases that can be solved using syahadah istifadhah. Al-Qaadi Abdul Wahhab narrated that syahadah istifadhah applies only to cases that are not changeable circumstances, or transfer of ownership in it such as the determination of nasab, death, waqf, and marriage.

Meanwhile, Ibn Rusyd al-Jadd quoted four others opinions on this. The first opinion, syahadah istifadhah can be received in all types of court cases. The second, syahadah istifadhah is not acceptable at all. The third syahadah istifadhah is accepted in all things except determining nasab, qadha', marriages, and deaths. And the fourth, syahadah istifadhah is not acceptable except in the four cases mentioned previously.

Next Ibn Syas, Ibn Hajib and the majority of fuqaha stated that syahadah istifadhah is allowed in some cases that have been restricted. Some jurists limit it to 20 (twenty) cases, others limit it to 21 (twenty one) cases, others limit it to 32 (thirty two) cases and among them who limit it to 49 (forty-nine) cases.

2. In the case of birth and nasab, Moslem scholars as quoted by Ibn alMundhir have consensused about the acceptance of determinating both of them through syahadah istifadhah.

3. The Hanbilah and some of fuqaha among Syafi'iyah stated allowance of itsbat through syahadah istifadhah on nine cases namely; marriages, absolute ownership, waqf and its distribution, death, asserting independence of slaves, relationship arrised caused by liberating the slave, guardanship and the release of position (Ibn Quddamah, 1983; Vol. 12, p. 23).

4. Some other fuqaha Syafi'iyah stated that testimony with istifadhah can not be used in the case of waqf, the relationship because the liberation of a slave, slave asserting independence, and husband and wife bond (Ibn Quddamah, 1983; Vol. 12, p. 23).

5. About this issue Abu Hanifa stated that testimony with istifadhah is not acceptable except in the case of marriage, death and nasab (Al-Kasani, 1986; Vol. 6, p. 267). 


\section{Between Testimonium De Auditu dan Syahadah Istifadhah}

Etimologically, the testimonium means witness. Campbell (1968; p. 1646) in his 1899 dictionary defines testimony as:

"Evidence given by a competent witness, under light or affirmation" or evidence given by a competent witness under oath or affirmation"

Furthermore, Campbell defines de audity as

"Evidence not proceeding from the personal knowledge of the withness, but from the mere repetition of what he has heard others say".

It means that the testimony of de auditu is not obtained testimony through knowledge, observation, and experience by the witness him self, but from what he had heard from others. Sudikno Mertokusumo (2009; p. 172) stated that the testimonium de auditu is witnesses obtained from third parties. For the example a third party knows firsthand that both parties then in the subject matter of case called plaintiff and defendant have ever made a debt agreement. The third party then tells his knowledge to the witness, then the witnesses testified that he heard from a third party and give information acquired from him before the judges. While Yahya Harahap (2005; p. 661) define testimony as witness or information based of hearing from other, also named as indirect testimony or not eyewitness experience. Related to this, Subekti (1999; p.42) narrated it with "the testimony from hearing". While Mukti Arto (1996; p. 164) define testimonium de auditu as witness not obtained directly by seeing, hearing and experiencing alone but rather through other people.

There is a cross of opinions among the experts of civil law about the power law of testimonium de auditu. The first opinion states that the testimonium de auditu is rejected as evidence. To reject or receive testimony de auditu as evidence is the General rules which still practised untill these days by law practitioners. This is effected by the rules which state that a witness who is not basing his statement from a source of knowledge as mentioned in articel 171 paragraph (1) of HIR and article 1907 paragraph (1) of KUH Perdata is not acceptable as the tool of evidence. In article 171 HIR mentioned that: "(1) Each witness must be accompanied by reasons of the knowledge of the witnesses, (2) Opinions or special persumptions that occurs as a result of thought are not categorized as the witness". In this case, Subekti (1999; p. 42) 
added that testimonium de auditu as information which is based on the views of others has no cost at all. Sudikno Mertokusumo (2009) gives similar opinion that in general, the testimony of de auditu is not allowed because the statement does not relate to events experienced directly. Thus, the witness de auditu is not constitute evidence then no need to be considered.

Second Opinion stated that the testimony of de auditu can be used as evidence by the various diverse application, including the following:

1. Testimonials de auditu accepted as evidence that stand-alone reached the minimum threshold of proof without the need for other evidence if the witness de auditu consists of several people. Witnesses who had qualified the formal and material requirements means that he has the power of free evidentiary value (Vrijbewijs Kracht). In other words, the judge has the freedom to assess the testimony in accordance with his conscience, the judge is not bound by the statements of the witnesses because the judge can only get rid of the witness testimony as long as he considers it sufficiently based on strong arguments or even judges may also receive information though a witness qualified testimonials de auditu as long as there is an exceptional basis to accept it. When the burden of proof by witnesses should be presented as the main witness in the case does not exist, then testimonials de auditu can be accepted as evidence that stand-alone reached the minimum limit of evidence if de audotu witness is consist of a few people or many. It is contained in the decision of the Supreme Court 239 K/Sip/1973 dated November 25, 1975. In its decision, the Supreme Court confirmed the de auditu testimonials can be used as evidence which fulfill the material requirement.

The testimony of witness in general is according to the message, but must be considered and almost all of the events or legal actions that occurred in the past has no letter, but based on hereditary message, while witnesses who directly face legal actions in the past no longer exists living now, and thus hereditary messages that can be expected as information and knowledge, and according to the judges themselves such a messages by a particular community considered valid and correct in general. However it should be noted from whom the message was received, also the person who gives 
information should be those who receive messages directly. It turns out that the problem was solved where the person who explained the message in the court was the person who immediately received the message.

There are several factors that become the basis to justify testimony de auditu as evidence, those are: first, the witnesses who directly involved in the events or legal actions tried have been died. Second, the events or legal actions can not be written in the form of a letter or other evidence that can be read and re-opened, as well as records, documents and so forth. Third, the information given by testimony de auditu was a message from the subjet or the person who is seen in events or disputed legal act and raised again before the tribunal as what he listens to (Asnawi, 2013; p. 155). In the matter of testimony de auditu, the underlying problems are not only about to accept the testimony as the evidence. But there is something more fundamental, which is how far the value of strength of evidence attached to it. It means that it is not so essential to polemize whether the testimonials de auditu can be admitted as evidence, therefore, it is no lonnger the time to reject automatically and say that it is not valid as evidence. Supposedly, it has to be received firstly and then consider is there any exceptional basis to accept it. If there were any, then consider the extent of the value of strength of testimony attached to the witness of testimony de auditu

2. Testimony de auditu is not used as a direct evidence but the testimony of de auditu constructed as evidence of conjecture (vermoeden) with objective and rational considerations and that prejudices can be used as a basis to prove something. Constructed as a presupposition here means that kind of witness does not disregard the overall of general rules that prohibits to receiv testimony de auditu testimony as the evidence. Which is preferred is the judges analyze the testimony de auditu then constructs the testimony as the allegation of evidence, and conducted on the basis of objective and rational (Asmuni, n.d; p. 196). As can be seen in the decision of the Supreme Court 308 K/ Pdt/1959 of November 11, 1959. Indeed, the decision still adheres the general rule prohibiting de auditu testimony as evidence, but to avoid the ban, the testimony 
was not considered as evidence of witnesses but constructed into evidence of conjecture (vermoeden).

In the decision of the Supreme Court dated 11 November 2011, No. 308 K/Sip/1959 states that "testimoniy de auditu" can not be used as direct evidence, but the use of testimony as a presupposition then use it to prove something, is not prohibited (Asmuni, n.d; p. 196). In the decision, it is very firmly stated that testimony de auditu cannot be used as a means of direct evidence, but his testimony can be applied as evidence of conjecture (vermoeden), and the conjecture can be used as the foundation to prove something.

This may be a question mark, but such a legal action is justified. Based on Article 1922 of KUH Perdata, Article 173 HIR, where the judge is given the authority to consider whether things can be realized as a means of allegation proof, as long as it is done carefully and thoroughly. In the application of de auditu testimony as allegation, the judge must be careful and precise. In this regard, it should be guided by the provisions mentioned in article 173 HIR which states:

"Mere presuppositions which are not based on specific legislation, should only be considered by the judge in making his decission if the allegation were accurate, specific, and each other has the conformity".

Presupposition evidence was regulated in article $173 \mathrm{HIR}$, and consists of only one chapter. So it can be said that it is brief, and does not cover all the essence things of the application of that evidence. Yahya Harahap (2005; p. 684) deciphers the meaning and process of conjecture as follows; First, the allegation that starts on the known facts, then the conclusion drawn towards matter with a concrete certainty which is previously unknown facts. Secondly, from the fact, then the conlusion is taken which is approaching certainty about the evidence of other facts previously unknown. Presupposition in article 1915 of KUH Perdata is divided into two types namely the allegation by the law or legislation (presumption of law, rechts vermoeden) and presumption of judges (presumption of fact, feitelijke vermoeden) (Asnawi, 2013; p. 68). The judge presupposition is conjecture based on the reality or facts derived from the facts proven at the trial. This is done by the judges as 
the law itself authorizes the judge in the form of freedom to compile assumptions (Harahap, 2005; p. 696). The strength of the evidence by the judge presupposition is free (vrij bewijskracht), means the judge freedom of how to conclude the allegation. But it will be strong and perfect proof and binding force if there is no other evidence that beat proof allegation made by the judge. Regarding this, the testimony de auditu is included indirectly into the means of allegation evidence which is not based on legislation (Harahap, 2005; p. 665). This because the role of judges is more dominant in reviewing of what has been described by a witness in order to complete the de auditu evidence in court cases. As for the strength of the evidence the judge's allegation is essentially free (vrij bewijskracht). If the presupposition of judge is unopposed or not overpowered by other evidence, the strength of the proof becomes perfect and binding.

3. Indeed, the witness should be more than one person with the minimum limit is two witnesses, when the limit cannot be fulfilled, it must be equipped. Unus testis nullus testis (one witness is no witness) can be encountered in the procedural law of both general and Religious Court. In this case, testimony de audito can be used as evidence to fulfill the minimum limit of unus testis nullus testis given by the witness. Thus the decision of the Supreme Court 818 K/Sip/ 1983 dated August 13, 1984. The decision stated that testimony de audito as useful information to strengthen the testimony of usual witness. In this case, the witnesses which were directly involved in the buying and selling only the first witness, while the second and third witness only qualified as de audito, but even so it turned out in the trial that information they convey was a result of direct knowledge derived from the defendant himself. Based on these facts, the Supreme Court argued that their testimony can be used as evidence corroborating the testimony of a witness.

Based on the explanation of the testimony de auditu, the authors find some points of similarities and differences between the concept of syahadah istifadhah in Islamic literatures and testimony de auditu as follows:

1. Wether syahadah istifadhah and testimony de auditu is a form of testimony obtained not from direct knowledge, observation, and 
the vision or the experience, but rather from what have been heard from others.

2. In the discourse of procedural law, syahadah istifadhah and testimony de auditu does not have any force of law unless it was based on several exceptions.

3. In a situation where the information about a certain matter has been widespread, syahadah istifadhah in fiqh discourse can be categorized as independent evidence. Likewise, any testimony de auditu can be used as evidence when the burden of proof by witnesses should be presented while the main witness in the case cannot be found and the information which has been spread in the community customarily considered as valid and correct information.

4. In the case of syahadah istifadhah, although there is a disagreement among Moslem intellectuals has set some of the civil cases where such evidence can be used while testimony de auditu has no any cases restrictions.

5. In some cases, shahadah istifadhah as it is called istifadhah which means widespread requires knowledge of many parties would get the case in order to be categorized as syahadah istifadhah (Wizarat Al-Awqaf wa As-Syu'un Ad-Diniyah, 1968; Vol. 26, p. 233). It is different from the concept of testimony de auditu that simply requires not gotten information directly in order to be categorized as a testimony de auditu as the antithesis of auditu testimony. According to the author, this is what led to the pros and cons of testimonials de auditu status as evidence.

\section{Absolute competence of The Religious Court and Syahadah Istifadhah in Case of Itsbat Waqf Absolut competence of Religious Court in Case Itsbat Waqf}

These days, the case of itsbat waqf began to be submitted to the Religious Court. This starts from the provisions of the law, especially article 17 of Law No. 41 Year 2004 which states that every legal act of waqf must be recorded and set forth in the deed of waqf statement by Pejabat Pembuat Akta Ikrar Waqf (PPAIW). In this case the deed of waqf statement considered as proof of authenticity as well as the 
guarantee in order to avoid fraud or encroachment without rights. Though the facts and reality of waqf in public in the past do not or do not have written proof. Among the causes is because waqf act in the past done only as the manifestation of the religious motivation to get closer to Allah with sincerity and generosity while the written evidence was ignored. Besides viewed from the perspective of Islamic jurisprudence, the past also did not require written evidence in any legal actions of waqff. It is then pushed many application to determinine waqf at some of the Religious Courts these days.

After many of itsbat waqf case submitted into the Religious Courts, the question arises related to the absolute competence of Religious Courts in handling such a case. It is because the provisions of Article 49 letter (e) of Law No. 3 Year 2006 arranged that Religious Court has a duty and authority to examine, decide and resolve cases at the first level among people who are Muslims in the areas of: (e) waqf.

In fact, Article 49 of Law No. 7 Year 1989 About the Religious Court and Article 49 of Law No. 3 Year 2006 on changes to Law No. 7 Year 1989 on the Religious Courts as the basis for determining the absolute competence of Religious Court did not explicitly explain the limitations of Religious Court authority to judge the case of waqf is it confined only to the format of a lawsuit (contentiuse) or also include application case of waqf ratification (volunteer).

The authority of the Religious Court in deciding the case of itsbat waqf all this time is only based on the result of decision of a National Working Meeting of MARI year 2007 in Makassar which among the formulations was deciding that the Religious Court is authorized to receive, examine, and decide upon confirmation of waqf with no deed of waqf statement, so the confirmation of itsbat waqf can be considered as basis for making the waqf land certificate.

The provisions of the procedural law court petition (voluntair) only under the authority of the Religious Courts when set explicitly in the legislation. While the case of itsbat waqf does not yet have any clear and certain legal basis unless the form of interpretation and the formulation of the National Workshop in Makassar year 2007 (Fanani, Fauzi, \& Abdurrahim, 2017; p. 15).

Those problems of course quite a dilemma, on the one hand the 
potential for Indonesian waqf is quite large. Other side, a legal vacuum occures in terms of authority of Religious Courts in dealing with itsbat waqf application. Therefore, it is necessary to study the solution of this problem, especially in order to optimize the role of waqf for national development. Here are some solutions for the problems found by author towards the problem of absolute authority of Islamic Court in terms of waqf determination (volunteer):

1. Related to Article 49 of Law No. 7 Year 1989 About the Religious Court and Article 49 of Law No. 3 Year 2006 on the change of Law No. 7 Year 1989 concerning the Religious Courts, as the basis for determining the absolute competence of courts that do not explicitly describes limitation of its jurisdiction is it confined only to the format of a lawsuit (contentiuse) or also include application case of waqf ratification (volunteer). In the event of a legal vacuum in this case, it can be overcome with the legal construction by analogizing (qiyas) itsbat waqf with itsbat nikah (marriage determining) as stipulated in Article 7 paragraph (2) Kompilasi Hukum Indonesia;

"In the case of marriage can not be proved with a marriage certificate, it can be submitted to the Religious Court in order to confirm its legitimation"

In Islamic jurisprudence it is supported by a legal basis that the determination of wedlock (al-'alaqah az-zaujiyah) as same as waqf is a kind of civil cases that its validity can be proven by the istifadhah testimony as stated by some Malikiyah, Hanabilah jurists and friends As- Shafi'I (Wizarat Al-Awqaf wa As-Syu'un Ad-Diniyah, 1968; Vol. 26, p. 233).

2. By referring article 49 Law No. 7 Year 1989 about the Religious Courts and article 49 of Law No. 3 year 2006 regarding changes to the Act No. 7 Year 1989 About the Religious Courts with article 58 paragraph (1) letter (c) of regulation Government No. 42 Year 2006 on the implementation of Law No. 41 Year 2004 About Waqf which requires the existence of "determination" from the Court to register waqf objects that have not been registered according to the legislation. This is as stipulated in determinatin No. 281/ Pdt.P/PA/2011/PA.Clg that use that kind of law interpretation as consideration of the absolute authority of Religious Court about this matter. 


\section{Syahadab Istifadhab in Case of Itsbat Waqf}

In handling these cases of itsbat waqf, obstacles often faced is related to the absence of witnesses who know directly legal acts of waqf that occurred in the past, because there are witnesses who have died. In this case, the available evidence is usually only witnesses who know that act of waqf indirectly based on information from others that have circulated widely in the community. Such testimony can be categorized as syahadah istifadhah (Asmuni, n.d; V. 3, No. 2, p. 198)

Syahadah istifadhah which is in some literature of Islamic jurisprudence referred by several terms such as syahadah bi at-tasamu' (testimony through mutual heard) or shahadah bi al-istifadhah (testimony with information which has been widespread) or alistifadhah min khalqin Ghafir (spread massively in widely) have the power as evidence. Muslim intellectuals have agreed on this point despite disagreement on which civil cases to use syahadah istifadhah (Wizarat Al-Awqaf wa As-Syu'un Ad-Diniyah, 1968; Vol. 26, p. 233). It is of course different from the concept of de auditu testimonials that do not require massive dissemination of information among the people. In addition, in order to be classed as a testimonials de auditu it is enough to hear information from others (including litigants) so that the statement is not based on the visions or her own experience. According to the author of such testimony is not the same as the principle of wide-spread information is the essencial key of syahadah istifahdhah to be accapted. In any condition, testimony de auditu can meet the criteria of syahadah istifadhah when the principle of wide-spread information was fulfilled. Otherwise, testimonium de auditu which cannot meet those criterias is more likely to be categorized as-syahadah bit-tasamu' (witness by hearing from others) which is more general than syahadah istifadhah (Wizarat Al-Awqaf wa As-Syu'un Ad-Diniyah, 1968; Vol. 26, p. 233).

In case of itsbat waqf, some jurist of Malikiyah such as Qadi Abdul Wahab, the 'alim of Hanbali, and some of Shafi'iyah scholars stated that syahadah istifadah is an evidence that can be used as long as the specified requirements have been fulfilled. (Wizarat Al-Awqaf wa As-Syu'un Ad-Diniyah, 1968; Vol. 26, p. 233). Therefore, the establishment of itsbat waqf request with syahadah istifadhah as the evidence is the right decision. 


\section{Conclusion}

Optmalisation of waqf in order to support national development is a necessity. In this case the Religious Court as an authorized institution in judging cases related to waqf has such a quite crucial role. In addition to present legal certainty, a Religious Court judges are also required to product the decission that also strengthens the role of waqf such as the determination of itsbat waqf with regard to the existing data and the law fact.

Determination of itsbat waqf with istifadhah testimony is such a quite impressive breakthrough. This suggests that the various legal determination methodology used by classic Islamic scholar in the past are still relevant today. In this case, the authors concluded that the sacrality of fiqh (Islamic jurisprudence) products should always be maintained, but the task of the judge is not fixated on the jurisprudence products. Judges are required to explore the methodology, the study scope of Islamic scholar, in order to achieve maslahah as the objectives of the law. Wallahu a'lamu bisshawab.[]

\section{References}

al-Abi al-Azhari Shalih Abd al-Sami'(nd), Jawahir al-Iklil Syarh Mukhtashar alAllamah as-Syaikh Khalil fi Madzhab al-Imam Malik Imam Dar at-Tanzil, Beirut: al-Maktabah al-Tsaqafiyah

Al-Kasani Al-Hanafi Abu Bakr Ibn Mas'ud (1986), Badai’ as-Shana'i’ fi Tartib alSyara',' Beirut: Daar al-Kutub al-'Ilmiyah

Al-Syarbini Muhammad Ibn Khatib (1997), Mughni al-Mubtaj ila Mảrifat Máani Alfadz al-Minhaj, Beirut: Daar al-Minhaj

al-Yảmari al-Maliki Abul Wafa Ibrahim Ibn al-Imam Syamsuddin Abu Abdillah Ibn Farhun (2003), Tabshirat al-Hukkam fi Ushul al-Aqdhiyah wa Manabij al-Ahkam, Riyadh: Dar 'alam al-Kutub

Arto A. Mukti (2004), Praktek Perkara Perdata pada Pengadilan Agama, Yogyakarta: Pustaka Pelajar

Asmuni (2014), "Testimonium de Auditu Telaah Perspektif Hukum Acara Perdata dan Fiqh" Jurnal Hukum dan Peradilan, Volume 3, Nomor 2, Jakarta: Balitbangkumdil MA-RI

Asnawi M. Natsir (2013), Hukum Pembuktian Perkara Perdata di Indonesia, Yogyakarta: UII Press

as-Shanhaji al-Mishri al-Maliki Syihab al-Din al-Qarafi/Abu al-Abbas Ahmad Ibn Idris Ibn Abdurrahman (2010), al-Furuq/Tahdzib al-Buruq bi Anwa' al- 
Furuq wa bihamisyihi Tahdzib al-Furuq wa al-Qawa'id as-Saniyah fi al-Asrar al-Fighiyah, Kuwait: Daar al-Nawadir.

Diana Rahmi (2013), "Ruang Lingkup Peradilan Agama dalam Mengadili Sengketa Ekonomi Syariah”, Syariah: Jurnal Hukum dan Pemikiran, Vol. 13, No. 2, Banjarmasin: UIN Antasari.

Djalil A. Basiq (2006), Peradilan Agama di Indonesia, Jakarta: Kencana.

Dr. Mardani (2009), Hukum Acara Perdata Peradilan Agama \& Mahkamah Syari'ah, Jakarta: Sinar Grafika.

Editorial (2017), "Dinamika Wakaf dan Tantangan Peradilan Agama”, Majalah Peradilan Agama Edisi 11, Jakarta: Direktorat Jendral Badan Peradilan Agama.

Fanani Ahmad Zaenal, Fauzi Achmad, dan Abdurrahim Mahrus (2017), "Problematika Penanganan Sengketa Wakaf", Majalah Peradilan Agama Edisi 11, Jakarta: Direktorat Jendral Badan Peradilan Agama.

Harahap M. Yahya (2005), Hukum Acara Perdata tentang Gugatan, Persidangan, Penyitaan, Pembuktian, dan Putusan Pengadilan. Jakarta: Sinar Grafika.

Harahap M. Yahya (2005), Kedudukan Kewenangan dan Acara Peradilan Agama Undang-undang Nomor 7 Tahun 1989, Jakarta: Sinar Grafika.

Henry Campbell Black, M. A (1986), Black's Law Dictionary, Cet. IV, Saint Paul: West Publishing Company.

Ibn Idris al-Buhuti Manshur Ibn Yunus (2000), Syarh Muntaha al-Iradat Daqa'iq Uli an-Nuha li Syarh al-Muntaha, Beirut: Mu'assasah al-Risalah Nasyirun.

Ibn Manzur al-Afriqi Al-Mishri Abi al-Fadhl Jamaluddin Muhammad Ibn Mukarram (1968), Lisan al-'Arab, Beirut: Daar Shadir.

Ibn Quddamah Abu Muhammad Abdullah Ibn Ahmad Ibn Muhammad (1983), al-Mughni wa yalih al-Syarh al-Kabir, Beirut: Daar al-Kutub al-Arabi.

Ibn Rusyd al-Qurthubi Abu al-Walid (1988), Al-bayan wa at-Tahshil wa as-Syarh wa al-Ta'lil fi Masa'il al-Mustakhrajah, Beirut: Daar al-Gharb al-Islami.

Ibn Salim ad-Dhuyan Ibrahim Ibn Muhammad (1959), Manar al-Sabil fi Syarh ad-Dalil 'ala Madzhab al-Imam al-Mubajjal Ahmad Ibn Hambal, Damaskus: Mansyurah Mu'assasah Dar Al-Salam.

Ibn Umar 'Abidin Muhammad Amin (2003), Rad al-Mukhtar 'ala ad-Dur alMukhtar Hasyiyah Ibn 'Abidin, Riyadh: Dar 'Alim 'al-Kutub.

Kencana Dr. Ulya, S.Ag, M.H (2017), Hukum WakafIndonesia; Sejarah, Landasan Hukum dan Perbandingan antara Hukum Barat, Adat, dan Islam, Malang: Setara Press.

M Noor Mohammad, Fathoni Ade Firman, \& Cholil Achmad (2017), "Potret Sengketa Wakaf di Indonesia", Majalah Peradilan Agama Edisi 11, Jakarta: Direktorat Jendral Badan Peradilan Agama.

M.D. Mahfud (1993), Kompetensi dan Struktur Organisasi Peradilan Agama: Peradilan Agama dan Kompilasi Hukum Islam dalam Tata Hukum Indonesia, Yogyakarta: UII-Press. 
Mertokusumo Sudikno (2009), Hukum Acara Perdata Indonesia, Yogyakarta: Liberty.

Subekti R. (1999), Hukum Pembuktian, Jakarta: Pradnya Paramita.

Sutantio Retnowulan dan Oeripkartawinata Iskandar (2009), Hukum Acara Perdata Dalam Teori dan Praktek, Bandung: Mandar Maju, 2009.

Syahrani Riduan (1991), Himpunan Peraturan Hukum Acara Perdata Indonesia, Bandung: Alumni.

Wizarat Al-Awqaf wa As-Syu'un Al-Islamiah Kuwait (1983), al-Mausuah alFiqhiyah al-Kuwaityah, Cet. II, Kuwait: Thiba'ah Dzat al-Salasil.

Penetapan Nomor 281/Pdt.P/2011/PA.Clg

Putusan Mahkamah Agung No. 239 K/Sip/1973 Tanggal 25 November 1975

Putusan Mahkamah Agung No. 308 K/Pdt/1959 tanggal 11 November 1959

Putusan Mahkamah Agung No. 818 K/ Sip/1983 tanggal 13 Agustus 1984

Undang-Undang No. 3 Tahun 2006 Tentang Peradilan Agama

Undang-Undang No. 41 Tahun 2004 Tentang Wakaf

UU No. 3 Tahun 2006 Tentang Peradilan Agama

Badan Wakaf Indonesia, Data Tanah Wakaf Seluruh Indonesia, accessed through https://bwi.or.id/index.php/ar/tentang-wakaf/data-wakaf/data-wakaftanah.html on April 15, 2018, at 08.22 P.M

Kamus Besar Bahasa Indonesia Dalam Jaringan (KBBI Daring) accessed through https://kbbi.kemdikbud.go.id/entri/testimoniumon April 23, 2018 at 17.07 P.M

Rifqi Qowiyul Iman, Religious Court of Ciamis, West Java. Email: rifqi1914@gmail.com 


\section{Mhliam}

AHKAM Jurnal Ilmu Syariah (ISSN: 1412-4734/E-ISSN: 2407-8646) is a periodical scientific journal published by Faculty of Sharia and Law of Syarif Hidayatullah State Islamic University Jakarta in collaboration with Indonesian Scientist and Sharia Scholar Association (HISSI). This journal specifically examines the science of sharia and obtains to present various results of current and eminence scientific research. The administrators receive articles as contributions Sharia and Islamic law disciplines from scientists, scholars, professionals, and researchers to be published and disseminated. The article will be situated in a selection mechanism, a review of proved reders, and a strict editing process. All articles published in this Journal are based on the views of the authors, but they do not represent the authors' journals or affiliated institutions.

AHKAM has been accredited based on the determination of Director General of Research Reinforcement and Development, Research, and Technology Ministry of Higher Education of Republic of Indonesia, No. 36/a/E/KPT/2016 (valid until 2021). 